\title{
Renewable energy sources (RES): alternative possibilities, which could be implemented in Poland
}

\author{
Anna Wiktor-Sułkowska1.a
}

${ }^{1}$ AGH University of Science and Technology

\begin{abstract}
The Kyoto Protocol and the EU's Renewable Energy Directive [1] are the World and the EU's legal regulations, which put pressure on most of the countries to extensive use of renewable energy sources (RES), in exchange for a reduction of energy from conventional sources. The main goal of the legal regulations is to reduce greenhouse gas emission. In European Union, from 1990 till 2014, share of the renewable energy sources has increased about 173\% [2]. The data show that RES share in energy mix is increasing, and still has to increase. Therefore, all European's countries are obligated to build new RES installations and to improve the efficiency of existing installations. That is the reason of that paper. In this article, on the base of own field research carried out in Germany and in Poland, author presents two alternative methods of energy obtaining, in which former mining excavations are used. In first method the excavations are adapted as the elements of the hydroelectric power stations and in second method they are used as a source of geothermal energy. In the end of the paper, author presents the proposals for the implementation of similar solutions in Poland.
\end{abstract}

\section{Introduction}

The directive 2009/28/EC of the European Parliament and Council says "The control of European energy consumption and the increased use of energy from renewable sources, together with energy savings and increased energy efficiency, constitute important parts of the package of measures needed to reduce greenhouse gas emissions and comply with the Kyoto Protocol to the United Nations Framework Convention on Climate Change, and with further Community and international greenhouse gas emission reduction commitments beyond 2012. Those factors also have an important part to play in promoting the security of energy supply, promoting technological development and innovation and providing opportunities for employment and regional development, especially in rural and isolated areas" [1].

It means that, the general policy of the European Union is to put pressure on Member States to extensive use of renewable energy sources (RES), in exchange for a reduction of energy from conventional sources. Figure 1 below shows share of energy sources in European Union, in years 1990-2014. It confirms that implementation of the policy is in advanced phase. In years 1990-2014 share of solid fuels in energy production has decreased about $60 \%$, and share of RES has increased about $173 \%$.

Table 1 below presents share of renewable sources of energy in European Union in 1990-2014. Among RES, the most important source is biomass and renewable wastes (over 64\% in 2014). Hydropower is the other main contributor to the renewable energy mix ( $16 \%$ in 2014).

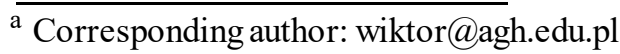

Data in Table 1 show that RES share is increasing and still has to increase. Therefore, all European's countries are obligated to build new RES installations and to improve the efficiency of existing installations. That is the reason of that paper.

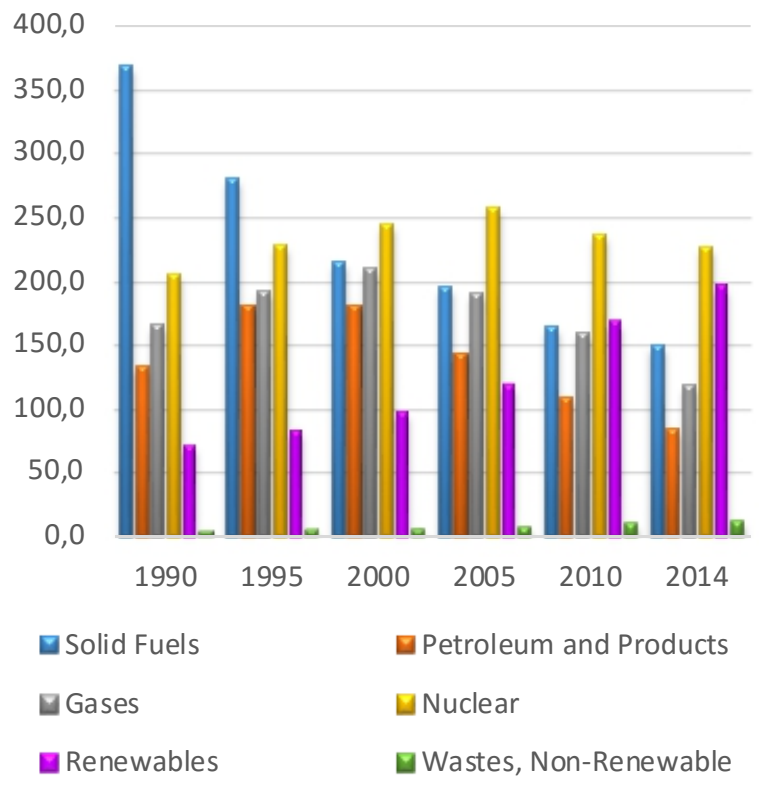

Figure 1. Share of energy sources in European Union (EU-28) in years 1990-2014 [Mtoe] (Source: Own elaboration based on [2])

In this article, author will present two alternative methods of energy obtaining, in which former mining excavations are used. In first method the excavations 
are adapted as the elements of a hydroelectric power station and in second method they are used as sources of geothermal energy. In the end of the paper author will present the proposals for the implementation of similar solutions in Poland.

Table 1. Gross Inland Consumption of RES in European Union (EU-28) in 1990-2014 [Mtoe] (Source: [2])

\begin{tabular}{|l|c|c|c|c|c|c|}
\hline Renewables & $\mathbf{1 9 9 0}$ & $\mathbf{1 9 9 5}$ & $\mathbf{2 0 0 0}$ & $\mathbf{2 0 0 5}$ & $\mathbf{2 0 1 0}$ & $\mathbf{2 0 1 4}$ \\
\hline Hydro & 25,0 & 28,5 & 30,7 & 26,9 & 32,4 & 32,2 \\
\hline Wind & 0,1 & 0,4 & 1,9 & 6,1 & 12,8 & 21,8 \\
\hline Solar & 0,1 & 0,3 & 0,4 & 0,8 & 3,7 & 12,0 \\
\hline $\begin{array}{l}\text { Biomass } \\
\text { and } \\
\begin{array}{l}\text { Renewable } \\
\text { Wastes }\end{array}\end{array}$ & 43,5 & 51,7 & 60,6 & 81,9 & 119,2 & 129,0 \\
\hline Geothermal & 3,2 & 3,4 & 4,6 & 5,3 & 5,5 & 6,2 \\
\hline
\end{tabular}

\section{Adaptation of former underground mine excavations as hydroelectric power stations}

The former mine excavations can be adapted as hydroelectric power stations. In the article, author presents two types of hydroelectric power stations located in mines undergrounds. The first type it is flow power station of special type. That type has been well known in Germany since $19^{\text {th }}$ century, but nowadays it impossible to find working installation like that. The second type is pumped storage plant, where energy can be accumulated. That type of hydroelectric power station is well known in surface space, but not in mines' excavations.

\subsection{Flow power station of special type}

These type of hydroelectric power station can be applied only in former mines, which will let for that. In that case, the mines have to have dewatering adits. Then water can naturally flow from surface reservoir through shaft, excavations, power generators, dewatering adit to the river. In that place the example of „Drei Brüder shaft” from Freiberg (Brand Ebisdorf, Sachsen, Germany) can be cited.

During the centuries Freiberg was well known from silver mining, but in the beginning of $20^{\text {th }}$ century exploitation of silver became less profitable, what resulted in local economic crisis. In 1899, the local authorities of Freiberg decided to change the local market profile from mining activity to energy production. The market transformation was supposed to help in industrialization process of the Brand Ebisdorf region.

In the beginning, they considered whether to produce energy from coal or using water. If they had produced energy from coal, then they would have had to import it specially. While, water has been brought to Freiberg form Erzgebirge's mines dewatering for over 500 years (for needs of that, $100 \mathrm{~km}$ of channels and 15 water reservoirs was built). Therefore, the local authorities have decided to use the potential of water by building the first in the world hydroelectric power station, was supposed to be located in mine's excavations.
In the "Drei Brüder shaft", at a depth of 272 meters, 4 power generators were installed. Officially, on $24^{\text {th }}$ of December 1914, first underground hydroelectric power station has started to produce the electricity. In 1922, the underground power plant was expanded by "Constantin Schacht," where 2 power generators were installed at a depth of $124 \mathrm{~m}$. The mine's excavations in total were able to hold 1.5 million $\mathrm{m}^{3}$ of water (Figure 2 ). The Freiberg's power plant then could reach power up to 5.6 MW.

Since 1953 , energy production has taken place only in the "Drei Brüder shaft" (Figure 3). In 1972, the power station has been shut [3].

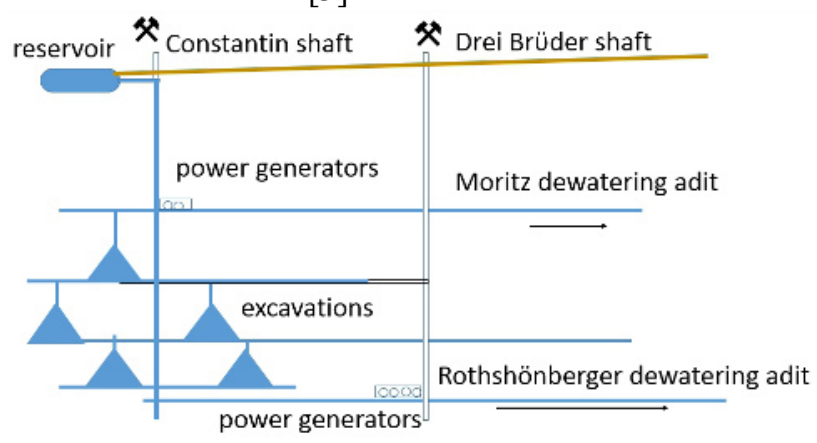

Figure 2. „Drei Brüder shaft" power station in 1922-1953 Source: Own elaboration based on [4]

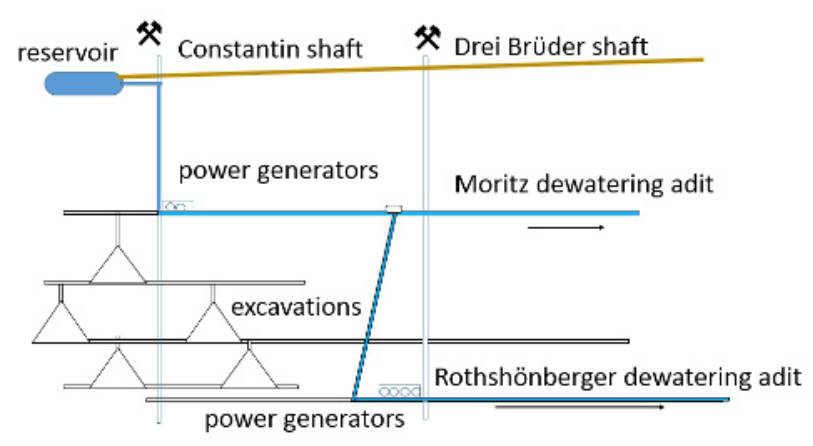

Figure 3. ,Drei Brüder shaft" power station in 1922-1953 Source: Own elaboration based on [4]

In the beginning of $20^{\text {th }}$ century power produced the power station could cover whole local industrial and urban demand for electricity. Nowadays, in Freiberg area demand for the electricity is about $40 \mathrm{MW}$. To cover that demand $90 \%$ of energy comes from a state network, and $10 \%$ comes from the local wind and solar farms. Simply it can be noticed, if the underground power station produced electricity, then local suppliers all together would cover more than $20 \%$ of local demand [3].

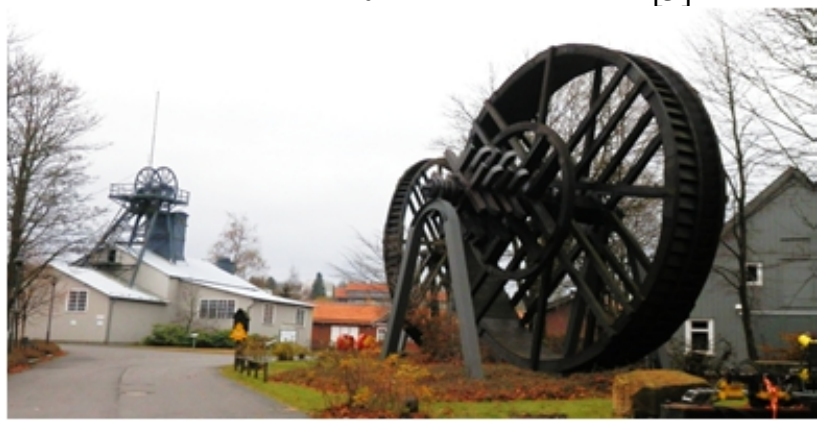

Figure 4. "Kaiser Wilhelm" shaft in Clausthal (Source: Own archive). 
Second example of flow power station of special type comes from Rammelsberg's mine (Goslar, Upper Hartz). In that mine special system of artificial ponds, channels, tunnels and underground drains has been built. Due to the system power of the water could be used in mining and metallurgical processes. In 1930, when mining activity has finished, the existing water system has been converted into a hydroelectric power plant generating electricity for the city. Power installed in the "Kaiser Wilhelm" shaft (Figure 4) could reached a maximum power of 4.5 MW, and the power installed in the "Ottiliae" shaft reached a power of $1.5 \mathrm{MW}$. The hydroelectric power plants in this region have been working till early 80 's of 20 th century.

\subsection{Pumped storage plant in former mines excavations}

These type of hydroelectric power stations is well known in surface space and is used for energy accumulation. Nowadays, demand for pumped storage plants is increasing, because of increasing need for renewable energy storing. Currently in Germany, two independent groups of scientists are investigating the possibility of adaptation of the mines excavations, as pumped storage, which could store the energy produced from RES (mainly wind and solar sources).

TU Clausthal conducted pilot research in ore mines "Pöhla" and "Grund". Initially, it has been estimated that approx. 104 German's ore mines could be adapted as a pumped storage plants. Each of them would have a capacity of $100 \mathrm{MW}$, and could generate an average power of $400 \mathrm{MWh}$, what means that all together could even generate about $40 \mathrm{GWh}$.

Figures below (Figure 5 and Figure 6) show the proposals of "Pöhla" and "Grund" mines excavations adaptation as the pumped storages plants. Both proposals are similar, it means that in those two examples both reservoirs (upper and lower) are underground. The difference is in the capacity of reservoirs and in the height between them. In the "Pöhla" mine, upper and lower reservoirs will have a capacity of 280 thousand. $\mathrm{m}^{3}$, and the difference in height between the reservoirs will be $600 \mathrm{~m}$. In the "Grund" mine reservoirs will have a capacity of 240 thousand. $\mathrm{m}^{3}$, while the difference in height will be about $700 \mathrm{~m}[5]$.

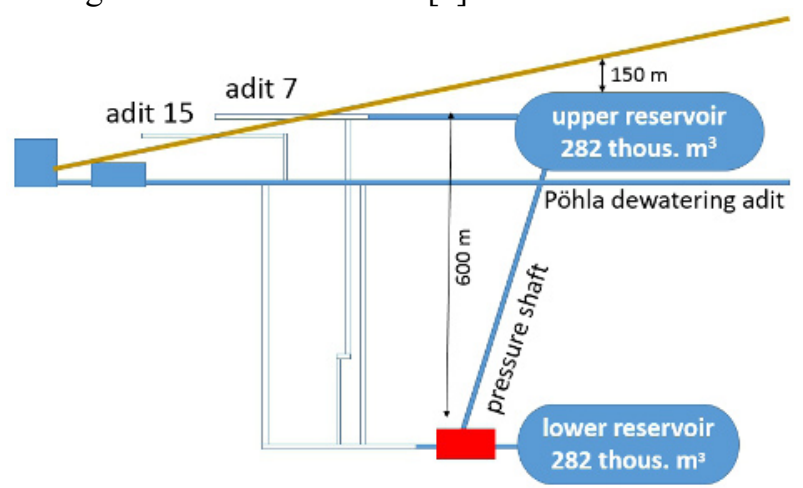

Figure 5. The scheme of pumped storage in "Pöhla" mine. Source: Own elaboration based on [6]

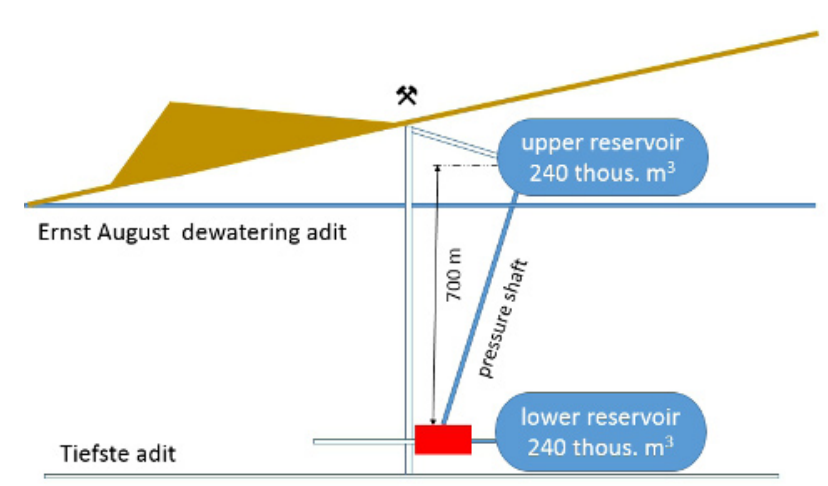

Figure 6. The scheme of pumped storage in "Grund" mine. Source: Own elaboration based on [6]

The total cost of the Bad Grund project is about 180 millions EUR, $60 \%$ of it that is cost of mine excavations adaptation [7].

University of Duisburg-Essen conduct the research in Ruhr area. In that case they examine the possibility of coal mines adaptation, as a pumped storage (Fig. 7). The results of the research will be known in 2018. Design assumptions predict location of the lower reservoir at a depth of $581-607 \mathrm{~m}$ and capacity of 600 thousand $\mathrm{m}^{3}$. The upper reservoir will be built in the surface. Expected power capacity is about $215 \mathrm{MW}$, and expected electricity production is about $880 \mathrm{MWh}$ [8].

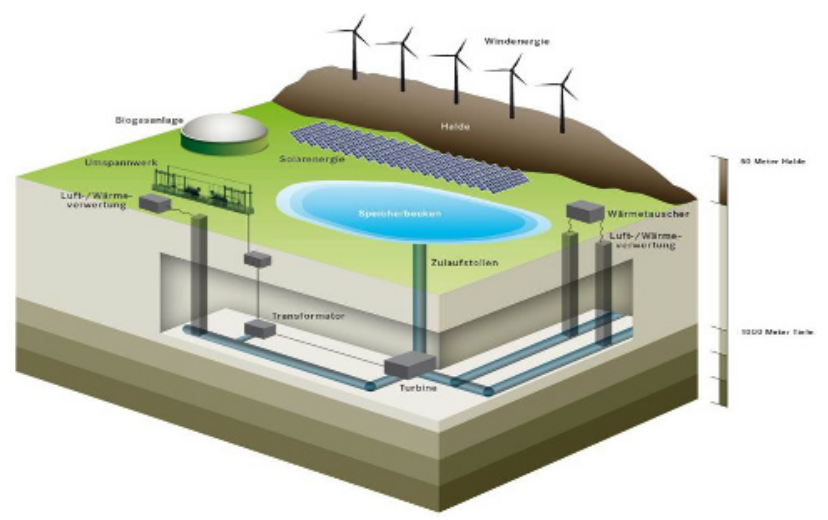

Figure 7. The scheme of pumped storage plant with surface and underground reservoirs. Source: [9]

\section{Mine excavations as a source of geothermal energy}

Mine water can be used as a medium in a geothermal heat pump installations, which can both, heat and cool the buildings.

The first geothermal heating system was installed in Essen, in 1982. Then hot water from "Henrich" mine heated the nursing house.

In Germany the geothermal heat pump installations are known very well. Only in Saxony is about 10 of them [10]. In the Freiberg area finds 4 geothermal heat pump installations, in Zwickau 1, in Bad Schlema 1, in Lugau/Olesnitz 1, in Marinienberg 1 and in Ehrenfriedersdorf 2 installations.

Table below shows selected examples of mine water use in geothermal heat pump installations. 
Table 2. Examples of installation, where the thermal energy of mine water is used (Source: Own elaboration based on [11-13])

\begin{tabular}{|l|c|c|c|c|c|}
\hline Place/Facility & $\begin{array}{c}\text { Deepth } \\
{[\mathrm{m}]}\end{array}$ & $\begin{array}{c}\mathrm{T}_{\text {hot }}\left[{ }^{\circ} \mathrm{C}\right] \\
{\left[{ }^{\circ} \mathrm{C}\right]}\end{array}$ & $\begin{array}{c}\mathrm{T}_{\text {cold }} \\
{\left[\mathrm{m}^{3} / \mathrm{min}\right]}\end{array}$ & $\begin{array}{c}\text { Water flow } \\
\text { rate } \\
{[\mathrm{kW}]}\end{array}$ \\
\hline $\begin{array}{l}\text { Reiche Zeche } \\
\text { Freiberg/Garmany }\end{array}$ & 228 & 18 & 14 & 2,4 & 670 \\
\hline $\begin{array}{l}\text { Zeche Robert } \\
\text { Müser } \\
\text { Bochum/Germany }\end{array}$ & 570 & 20 & - & 3,07 & 1600 \\
\hline $\begin{array}{l}\text { Schacht 302 } \\
\text { Marienberg/ } \\
\text { Germany }\end{array}$ & 107 & 12,4 & 7,4 & 2 & 690 \\
\hline $\begin{array}{l}\text { Zinngrube } \\
\text { Ehrenfriedersdorf/ } \\
\text { Germany }\end{array}$ & 110 & 10 & 4 & 0,36 & approx. 100 \\
\hline $\begin{array}{l}\text { Gewerbegebiet } \\
\text { Reden/Germany }\end{array}$ & 900 & 30 & ------ & ---------- & 450 \\
\hline $\begin{array}{l}\text { Zeche Henrich } \\
\text { Essen/Germany }\end{array}$ & $335-$ & 22 & ------ & 0,33 & 354 \\
\hline $\begin{array}{l}\text { Saturn } \\
\text { Czeladź/Poland }\end{array}$ & 194 & 12 & ------ & 15,10 & 106,8 \\
\hline
\end{tabular}

In Freiberg, first geothermal heating system was installed in 1990. Then water from "Reiche Zeche" shaft heated the foreman's building. Currently, "Reiche Zeche's" water (approx. $18^{\circ} \mathrm{C}$ ) is used, among others, in heating systems of: city hospital, buildings located near to "Reiche Zeche" shaft, one new building of TU Bergakademie and the "Freudenstein" castle. While, water from the same mine, but gathered in other place, in "Rothschönberger" adit (approx. $14^{\circ} \mathrm{C}$ ), is used in cooling systems [14-15].

In Ruhr area mine water has to be pumped up from the former mine "Robert Müser" for safety reason. That water has temperature of $50^{\circ} \mathrm{C}$. In Bochum has been running the project, where "Robert Müser's" mine water is used in heating installations of: primary school, secondary school with a canteen and swimming pool and the main fire station. It has been calculated that due to these investments annually the buildings saves 1,200 MWh, and thus reduces the $\mathrm{CO}_{2}$ emissions by 245 tons [16].

The geothermal heat pump systems, with mine water as a medium, finds also in Canada, the Netherlands, Czech Republic, Scotland and in Poland. However, any of that countries do not have as much the geothermal heat pump systems as Germany has.

The first, and still only one, polish geothermal heat installation has been working since 2012. Water from "Saturn" mine is used in heating and cooling system of building, which is located next to the shaft.

Table 3. Economical effect of polish geothermal heating installation (Source: [12])

\begin{tabular}{|c|c|}
\hline heating system & $\begin{array}{c}\text { cost } \\
\text { [thous. PLN/year] }\end{array}$ \\
\hline Electric & 80,3 \\
\hline heating pumps & 13,5 \\
\hline yearly savings & 66,8 \\
\hline
\end{tabular}

The heating pump installation have costed 352 thousand. PLN. It has been counted that annual savings, $\mathrm{W}$ arise from the use of heat pumps can reach 66,8 thousand PLN, so the investment should be recouped after 5-6 years (Table 3).

\section{Proposals for the implementation of similar solutions in Poland}

If European Union continues to put pressure on Member States regarding to increasing RES share in energy production, then will increase the demand for this energy storage. Already, it is worth to consider the possibility of the former mine workings adaptation as the pumped storages. Especially, taking into account the fact, that in Poland, before implementation of restructuring program, it operated more than 70 coal mines, currently more than 30 still is in operation. All of polish coal mines have approx. $300 \mathrm{~km}$ of excavations, what gives huge energy storage potential.

Mine Dewatering Institute (CZOK) has to dewater some of former mines of Upper Silesia region from safety reasons. Yearly it has to pump more than $70 \mathrm{~m}^{3}$ of mine water. The temperature of the water is between 10 to $28^{\circ} \mathrm{C}$ (vide App. 1). These water could be used in heating and cooling installations. Unfortunately, instead of this, mine water is discharged into surface watercourses, as a waste water. CZOK has to pay environmental fee, which is approx. 8 million PLN / year. In author's opinion, this indicates a lack of economic thought, and a great waste of potential, which carries a mine water.

\section{Summary}

In this article, on the base of own field research carried out in Germany and in Poland, author has presented two alternative methods of energy obtaining, where former mining excavations are used. In first method the excavations were adapted as the elements of the hydroelectric power stations (flow power station of special type and pumped storage plant) and in second method they were used as a source of geothermal energy.

In the article two the examples has been shown: from Freiberg ("Drei Brüder" shaft) and from Goslar ("Rammelsberg" mine), where were installed flow power stations of special type. That type of hydroelectric power station has been well known in Germany since $19^{\text {th }}$ century, but nowadays it impossible to find working installation like that. These type of hydroelectric power station can be implemented only in specific former mines. In that case, the mines have to have dewatering adits, then water can naturally flow from surface reservoir through shaft, excavations, power generators, dewatering adit to the river. Nowadays, it is hard to find mine like that, because dewatering adits has been turned into water pumped systems.

In next part of paper were shown the examples of "Pöhla" and "Grund" (ore mines), and the example from the Ruhr area (coal mines), where mines excavations were supposed to be adapted as reservoirs of pumped storage plants. Poland has huge energy storage potential, where coal mines excavation could be adapted as reservoirs. 
In further part of the article was also indicated that mine water can be used as a medium in a geothermal heat pump installations (both heating and cooling). In these part few examples from Germany and one from Poland were presented. The geothermal heat pump systems finds also in Canada, the Netherlands, Czech Republic, and in Scotland. However, any of that countries do not have as much the geothermal heat pump systems as Germany has. Actually in Poland is only one installation like that. Poland has huge thermal potential of mine water (app.1), but it is totally untapped.

The world and EU's policy can contribute to the development of alternative adaptation of former mine excavations.

Due to adaptation of former mines excavations as RES Poland could save carbon dioxide emission units.

\section{Acknowledgements}

Source of financing: university grant no. 11.11.100.693, task no. 4.

\section{References}

1. European Commission, Directive 2009/28/ec of the european parliament and of the council on the promotion of the use of energy from renewable sources and amending and subsequently repealing Directives 2001/77/EC and 2003/30/EC, (European Commission, 2009)

2. European Commission, EU Energy in figures. Statistical Pocketbook 2016, (Publications Office of the European Union, Luxembourg, 2015)

3. M. Schonfeld, J. Leisner, Power Station in Drei Bruder Schacht, (Interview, 15th of August 2012)

4. Supaplex,[Online],Available:https://de.wikipedia.o rg/wiki/Drei-Br\%C3\%BCder-Schacht (2016)

5. P. Beck, M. Schmidt, Pumpispeicherwerken in ehemaligen Erzgruben, Konception einer Pilotanlage im Harz, (Energie-Forschungszentrum Niedersachsen, Zollverein, 2011)

6. P. Beck, M. Schmidt, Windenergiespeicherung durch Nachnutzung stillgelegter Bergwerke, (Goslar: Universitätsbibliothek Clausthal, 2011)

7. ndr.de, Konnen Pumpischer Atomkraftwerke ersetzen?

[Online].Available:http://www.ndr.de/regional/nide rsachsen/harz/harz267.html (11 th of May 2011)

8. A. Niemman, Sachstand zur Machbarkeitsstudie einer Nachfolgenutzung der Anlagen des Steinkohlebergbaus im Ruhrgebiet als Pumpspeicherwerke, (Universitat Dissburg, Essen, 2014)

9. Universitat Disburg Essen, UnterflurPumpspeicherkraftwerke, [Online]. Available: http://www.unidue.de/imperia/md/images/wasserba u/upw_600.jpg (7th of April 2016)

10. P. Horler, Der Bergbau in Sachsen, (Freiberg: ReproMedia $\mathrm{GmbH}, 2012$ )

11. T. Grab, Storch T. and others, Geothermieanlage zur Grubenwassernutzung für Heizung (200 - 670 $\mathrm{kW})$ und Kühlung (155 - $500 \mathrm{~kW}$ ), (Der Geothermiekongress. 17-19 November 2010, Karlsruhe, 2010)
12. CZOK, Vademecum CZOK, (Czeladź, 2012)

13. EnEff:Stadt, Wärme aus Grubenwasser in BochumWerne, [Online]. Available: http://www.eneffstadt.info/de/waerme-und-

kaeltenetze/projekt/details/waerme-ausgrubenwasser-in-bochum-werne/, (16th of Martz 2014)

14. K. Grunt, Reiche Zeche und Alte Elizabeth, (Interview, 15th of July 2012)

15. C. Drebenstedt, Mining in Germany (Interview, 1st of August 2012)

16. Ch. Geimer, Thermal heat from pit water," FIZKarlsuhe, (Leibnitz Institute for Information Infrastructure, Eggenstein-Leopoldshafen, 2013)

17. A. Niemann, E. Perau, K. Schreiber and others, Chancen und Risiken untertägiger Pumpspeicherwerke in Steinkohlebergwerken im Ruhrrevier (Zeitschrift Wasserwirtschaft 1/2, pp. 66-69, 2014)

18. A. Jasińska, A. Czaplik, Mine Dewatering Institute in Czeladź, (Intervew, 23th of January 2013) 
Appendix 1. Upper Silesia's former coal mines water (Source: Own elaboration based on [12])

\begin{tabular}{|c|c|c|c|c|c|c|c|c|}
\hline \multicolumn{2}{|c|}{ Pump station } & $\begin{array}{l}\text { Pumping } \\
\text { system }\end{array}$ & $\begin{array}{c}\text { Deep of } \\
\text { pumping } \\
{[\mathrm{m} \mathrm{ppt}]}\end{array}$ & $\begin{array}{c}\text { Range of pumping } \\
\text { [m.a.s.l. }]\end{array}$ & $\begin{array}{l}\text { Water } \\
\text { category }\end{array}$ & $\begin{array}{c}\text { Total amount } \\
\text { of pumped } \\
\text { water in } 2012 \\
\text { [thous. } \mathrm{m}^{3]}\end{array}$ & $\begin{array}{l}\text { Amount of } \\
\text { pumped } \\
\text { water } \\
{\left[\mathrm{m}^{3} / \mathrm{min}\right]}\end{array}$ & $\begin{array}{c}\text { Water } \\
\text { temperature } \\
{\left[{ }^{\circ} \mathrm{C}\right]}\end{array}$ \\
\hline \multicolumn{2}{|c|}{ "Saturn" } & \multirow{9}{*}{ deep } & 194 & $+83,0 /+86,0$ & IV & 7935 & 15,10 & 12,0 \\
\hline \multicolumn{2}{|c|}{ "Grodziec" } & & 274 & $+110,0 /+115,0$ & IV & 1359 & 2,40 & 13,3 \\
\hline \multicolumn{2}{|c|}{ "Sosnowiec" } & & 227 & |------------------- & III & 3329 & $13,00^{*}$ & 13,4 \\
\hline \multicolumn{2}{|c|}{ "Paryż" } & & 213 & $+80,0 /+85,0$ & III & 94 & 9,50 & 12,9 \\
\hline \multicolumn{2}{|c|}{ "Porąbka-Klimontów" } & & 482 & $-203,0 /-200,0$ & IV & 2864 & 5,40 & 17,0 \\
\hline \multicolumn{2}{|c|}{ "Niwka-Modrzejów" } & & 411 & $-175,0 /-160,0$ & $\mathrm{~V}$ & 5873 & 11,10 & 17,5 \\
\hline \multicolumn{2}{|c|}{ "Katowice" } & & 483 & $-204,5 /-198,5$ & $\mathrm{~V}$ & 2800 & 5,30 & 18,0 \\
\hline \multicolumn{2}{|c|}{ "Kleofas" } & & 642 & $-365,0 /-358,0$ & $\mathrm{~V}$ & 3246 & 6,20 & 21,4 \\
\hline \multicolumn{2}{|c|}{ "Gliwice" } & & 498 & $-270,0 /-266,0$ & $\mathrm{~V}$ & 2902 & 5,50 & 21,3 \\
\hline \multirow{2}{*}{\multicolumn{2}{|c|}{ "Pstrowski" }} & \multirow{2}{*}{ stationary } & 575 & $-297,0$ & $\mathrm{~V}$ & 8386 & 5,86 & 18,8 \\
\hline & & & 825 & $-559,0$ & & & 10,04 & 25,8 \\
\hline \multirow{2}{*}{\multicolumn{2}{|c|}{ „Szombierki” }} & \multirow{2}{*}{ stationary } & 630 & $-370,4$ & $\mathrm{~V}$ & 2399 & 3,91 & 24,5 \\
\hline & & & 790 & $-502,8$ & & & 0,65 & 27,6 \\
\hline \multirow{3}{*}{\multicolumn{2}{|c|}{ „Powstańców Śl.” }} & \multirow{3}{*}{ stationary } & 500 & $-213,0$ & \multirow{3}{*}{$\mathrm{V}$} & \multirow{3}{*}{1421} & 0,62 & 21 \\
\hline & & & 650 & $-356,0$ & & & 1,04 & 24,2 \\
\hline & & & 760 & $-467,5$ & & & 1,08 & 23,8 \\
\hline \multirow{7}{*}{\multicolumn{2}{|c|}{ „Dębieńsko” }} & \multirow{7}{*}{ stationary } & 112 & $+136,0$ & \multirow{7}{*}{$\begin{array}{l}\text { III } \\
\text { V }\end{array}$} & \multirow{7}{*}{$\begin{array}{l}1727 \\
3207\end{array}$} & 1,61 & 10,7 \\
\hline & & & 202 & $+46,8$ & & & 0,74 & 12,2 \\
\hline & & & 310 & $-60,92$ & & & 0,44 & 15,4 \\
\hline & & & 410 & $-161,2$ & & & 3,89 & 15,8 \\
\hline & & & 600 & $-350,0$ & & & 2,28 & 21,3 \\
\hline & & & 690 & $-440,2$ & & & 0,31 & 26,7 \\
\hline & & & 781 & $-531,25$ & & & 0,04 & ---------- \\
\hline \multicolumn{6}{|c|}{ Total inflow } & & 9,43 & \\
\hline \multirow{4}{*}{ 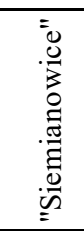 } & stationary & \multirow{4}{*}{ stationary } & 206 & $-27,0$ & \multirow{4}{*}{ IV } & \multirow{4}{*}{15648} & 8,12 & 14,0 \\
\hline & $\begin{array}{l}\text { pomp. } \\
\text { "Bańgów" } \\
\text { p.206 m. }\end{array}$ & & 321 & $-38,0$ & & & 3,10 & 17,0 \\
\hline & pomp. & & 321 & $-23,5$ & & & 4,98 & 17,0 \\
\hline & "Chorzów" & & 630 & $-338,0$ & & & 6,90 & 20,0 \\
\hline \multicolumn{6}{|c|}{ Total inflow } & & 23,10 & \\
\hline & Kanty" & stationary & 270 & $+11,9$ & III & 12654 & 24,00 & 11,4 \\
\hline
\end{tabular}

